\title{
デビトライト(六ケイ酸三カルシウムニナトリウム) $\mathrm{Ca}_{3} \mathrm{Na}_{2} \mathrm{Si}_{6} \mathrm{O}_{16}$ の結晶構造
}

\author{
井原将昌・小谷和司・吉田直次郎・福 永二郎 - 瀬戸口正宏* - 東 常 行**

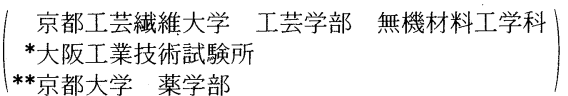

ソーダ石灰ガラスから失透する鉱物の一つである，デビトライトの結晶構造を単結晶 X 線法で 解析した. $\mathrm{Na}_{2} \mathrm{MoO}_{4}$ を融剂として, 白金るつぼ中で $910^{\circ} \mathrm{C} て ゙ 193$ 時間保持して $1 \times 0.008 \times 0.008$ $\mathrm{cm}$ の単結晶を作った。この結晶は三斜晶系で空間群は $P \overline{1}$, 構造式は $\mathrm{Ca}^{[5]} \mathrm{Ca}_{2}{ }^{[6]} \mathrm{Na}^{[6]} \mathrm{Na}^{[7]} \mathrm{Si}_{6}{ }^{[4]} \mathrm{O}_{16}$ で ある. 本結晶のケイ酸塩陰イオン群はワラストナイト結晶を構成する 3 個の $\mathrm{SiO}_{4}$ を周期とする単 鎖 4 本が縮合した 4 重鎖である。この 4 重鎖は $c$ 軸方向に並び, 各々は $\mathrm{Ca}^{2+}, \mathrm{Na}^{+}$両イオンのみ で相互に結合している．この結晶は 4 員環，6員環及び 8 員環を含む. Belovによると, 半径の大 きい陽イオンや中程度の半径の陽イオンを含むケイ酸塩群中にはこれら 3 種類の環と同等のものが しばしば存在する. $\mathrm{SiO}_{4} 4$ 面体は少しひずんでおり， $\mathrm{Si}-\mathrm{O}_{\mathrm{nb}}$ 結合が $\mathrm{Si}-\mathrm{O}_{\mathrm{b}}$ 結合より短い. $\mathrm{Ca}^{2+}$ と $\mathrm{Na}^{+}$の陽イオン間距離は $3.5 \AA$ と $4.0 \AA$ の付近に集中している.

(1983 年 11 月 7 日受付)

\section{The Crystal Structure of Devitrite (Disodium Tricalcium Hexasilicate), $\mathrm{Ca}_{3} \mathrm{Na}_{2} \mathrm{Si}_{6} \mathrm{O}_{16}$}

\author{
Masayoshi IHARA, Kazushi ODANI, Naojiro YOSHIDA, Jiro FUKUNAGA, \\ Masahiro SETOGUCHI* and Tsuneyuki HIGASHI** \\ Department of Inorganic Materials, Kyoto Institute of Technology \\ Matsugasaki, Sakyo-ku, Kyoto-shi 606 \\ *Government Industrial Research Institute, Osaka \\ **Faculty of Pharmaceutical Sciences, Kyoto University
}

Devitrite often crystallizes from soda lime glass in tank furnaces as devitrified stones. It is interesting to know its crystal structure in relation to the structure of soda lime glass. Devitrite crystals up to $10 \mathrm{~mm} \times 0.08 \mathrm{~mm} \times 0.08 \mathrm{~mm}$ were grown by the flux method, using sodium molybdate as a flux. Unit cell dimensions with mean standard deviations are $a=10.123 \pm 0.01$ $\AA, b=10.659 \pm 0.009 \AA, c=7.117 \pm 0.005 \AA, \alpha=109.71 \pm 0.073^{\circ}, \beta=98.24 \pm 0.08^{\circ}, \gamma=78.15$ $\pm 0.06^{\circ}$. Intensity data were collected at 2222 reciprocal lattice points by a four-circle single crystal automatic diffractometer, using $\operatorname{Mo} K \alpha$ radiation. The structure was assumed to belong to the space group of $P 1$ or $P \overline{1}$ because the Wilson statistical method failed to confirm the exsitence of the center of symmetry. The structures were solved by the direct methods, using the MULTAN 78 program system and refined by the method of least-squares using a block diagonal matrix program. The refined structures had the same $R$ value of 0.092 which corresponded to both space groups of $P 1$ and $P \overline{1}$. As the structures obtained were similar, the space group $P \overline{1}$ was chosen to represent the structure. The crystal has the structural formula $\mathrm{Ca}^{[5]} \mathrm{Ca}_{2}{ }^{[6]} \mathrm{Na}^{(6)} \mathrm{Na}^{(7)} \mathrm{Si}_{6}{ }^{[4]} \mathrm{O}_{16}$, where the coordination numbers are indicated in brackets. The silicate poly-anions in devitrite are one dimensional quadruple chains (the devitrite band) which run parallel to the $c$-axis and are bonded to each other only by $\mathrm{Ca}^{2+}$ and $\mathrm{Na}^{+}$ions. As suggested by Belov for the silicate groups having large and middle size cations, the devitrite band can also be formed by the condensation of wollastonite chains into a structure containing 8-, 6- and 4-membered rings, according to the following equations,

(wollastonite chain $\rightarrow$ xonotolite band $\rightarrow$ devitrite band)

$2\left[\mathrm{Si}_{3} \mathrm{O}_{9}\right]_{\infty}-\mathrm{O}=\left[\mathrm{Si}_{6} \mathrm{O}_{17}\right]_{\infty}, 2\left[\mathrm{Si}_{6} \mathrm{O}_{17}\right]_{\infty}-\mathrm{O}=\left[\mathrm{Si}_{12} \mathrm{O}_{33}\right]_{\infty}$

Experimental results show that the $\mathrm{SiO}_{4}$ tetrahedra are somewhat distorted, and $\mathrm{Si}-\mathrm{O}_{\mathrm{nb}}$ bonds are shorter than $\mathrm{Si}-\mathrm{O}_{\mathbf{b}}$ bonds. The closest separations between cations in the crystal often have the values of about $3.5 \AA$ and about $4.0 \AA$.

[Received November 7, 1983] 
Key-words : Devitrite, $\mathrm{Ca}_{3} \mathrm{Na}_{2} \mathrm{Si}_{6} \mathrm{O}_{16}$, Ca-silicate, Na-silicate, Flux method, Quadruple chain, $\mathrm{SiO}_{4}$ ring, Single crystal, X-ray, Atomic structure

\section{1. 緒 言}

$\mathrm{Ca}_{3} \mathrm{Na}_{2} \mathrm{Si}_{6} \mathrm{O}_{16}$ は $\mathrm{Na}_{2} \mathrm{O}-\mathrm{CaO}-\mathrm{SiO}_{2}$ 系状態図の中で, 実用ソーダ石灰ガラスの組成範囲に初相域を有している 結晶の一つであり，これらのガラスからしばしば失透 (devitrify) してくる化合物であるから，デビトライ 卜 (devitrite) と命名された . 牧らはデビトライトの $\mathrm{Na}_{2} \mathrm{O}$ をその総量の $20 \mathrm{~mol} \%$ 程度以上 $\mathrm{K}_{2} \mathrm{O}$ で置き換え た組成の固溶体は不安定で, 固相反応では合成できない が，その固溶体と同一組成のガラスを $1000^{\circ} \mathrm{C}$ 付近で加 熱すると, 最初にそのガラスと同一組成のデビトライト 固溶体が単一の相として直接晶出し，これが加熱の持続 により分解してワラストナイトを析出すると報告してい る2). デビトライトは，このようにガラスから直接晶出 する結晶であるから，その母体ガラスと構造の関連性が 大である可能性が強い。そこで，デビトライトの結晶構 造をX 線法で解明し，ソーダ石灰ガラスの構造推定の 一つの資料にするのが本研究の目的である.

\section{2. 実験}

\section{1 単結晶の作製}

牧は $\mathrm{Ca}_{3} \mathrm{Na}_{2} \mathrm{Si}_{6} \mathrm{O}_{16}$ 組成のガラスを失透させ, $\mathrm{X}$ 線研 究に使用できる単結晶を育成した ${ }^{3)}$. しかし, 詳細な育 成条件を報告していない，そこで，失透温度並びに時間 を種々変更して，この化合物と同一組成のガラスを結晶 させたが, 本研究では単結晶構造解析に充分な大きさの 良質の単結晶は得られなかった。他方，小谷らは $\mathrm{Na}_{2} \mathrm{MoO}_{4}$ を融剤として単結晶構造解析に利用可能な大 きさの単結晶を得た ${ }^{41}$. 小谷の方法に従い, 半井化学薬 品製の特級試薬の $\mathrm{CaCO}_{3}, \mathrm{Na}_{2} \mathrm{CO}_{3}, \mathrm{SiO}_{2}$ を結晶の原 料とし, 溶媒 $\mathrm{Na}_{2} \mathrm{MoO}_{4}$ （半井化学薬品, 特級) に溶質 原料混合物 $\left(\mathrm{Ca}_{3} \mathrm{Na}_{2} \mathrm{Si}_{6} \mathrm{O}_{16}\right.$ 換算) 対溶媒比 $1: 50$ でよ

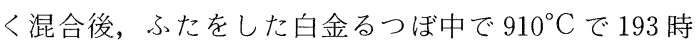
間加熱後炉内放冷した．溶媒を水洗除去し，粉末 X 線 法で, デビトライト結晶のみが生成していることを確認 した。この育成条件ではデビトライト結晶は化学量論比 のものとなり，溶媒からのMoの混入率も $0.1 \%$ 以下 であることが EPMA 分析で確かめられている ${ }^{4 !}$. 得ら れたデビトライト単結晶は細長い棒状で, 長さ $1 \mathrm{~cm}$ 以 上に成長した単結晶でも太さは $0.01 \mathrm{~cm}$ 以上には成長 しない。この結晶は長さ方向に平行な面で容易に䢃開し， ほぼ四角形の割れ口を有する小結晶片になりやすいの で，これを球形に整形することは困難であった。回折実 験には $0.018 \times 0.008 \times 0.008 \mathrm{~cm}$ の角柱で，稜のすこし 削れた形状の結晶を使用した。

\section{2. 回折強度の測定}

大阪工業技術試験所の理学電機製自動 4 軸型回折計 で，上記結晶の各網面よりの回折強度を $M \circ K \alpha$ 線を用 いて測定した. 各原子の質量吸収係数から計算した線吸 収係数は $16 \mathrm{~cm}^{-1}$ であるから，ほとんど吸収補正の必要 がないと考えられるが，この結晶を半径 $0.004 \mathrm{~cm}$, 長 さ $0.018 \mathrm{~cm}$ の円筒形と仮定し，更にこれを 320 個の小 片にわけて吸収量を計算し強度補正を行った. 結晶の $b$ 軸が 4 軸型回折計の $\phi$ 軸にほぼ一致するように取り付 け，赤道面反射法を用いたが，吸収補正前後それぞれの 回折強度に基づく結晶構造は同類のものとなり，また吸 収補正は最終の信頼度因子， $R$ にはほとんど影響しな かった. 更に, 常法によりローレンツ因子及び偏光因子 に対する補正を行った。 4 軸型回折計による格子パラ メーター測定值は, $a=10.097 \AA, b=10.656 \AA, c=$ $7.118 \AA, \alpha=109.73^{\circ}, \beta=98.21^{\circ}, \gamma=78.15^{\circ}$ となり, 先に小谷ら"が粉末 $X$ 線回折法で精密化した格子パラ メータ一值 $a=10.123 \pm 0.01 \AA, b=10.659 \pm 0.009 \AA$, $c=7.117 \pm 0.005 \AA, \quad \alpha=109.71 \pm 0.073^{\circ}, \quad \beta=98.24 \pm$ $0.08^{\circ}, \gamma=78.15 \pm 0.06^{\circ}$ と良い一致を示した.このパ ラメーターで指数付けした回折点には, 回折点の規則的 消滅は見いだされない。これらの回折強度から規格化構 造因子， $E$ を計算し，Wilson 統計法で対称心の有無を 調べた. $\langle|E|\rangle=0.867\left\langle\left.|| E\right|^{2}-1 \mid\right\rangle=0.804$ で, 対 称心のある場合, ない場合のいずれの理論値とも一致せ ず，この結果からは対称心の有無を決定できなかった.

\section{3 結晶構造の解析}

前述のごとくWilson 統計法で対称心の有無が判断で きぬので, $P 1$ と $P \overline{1}$ の両空間群それぞれの場合に対し て結晶構造を調べた。

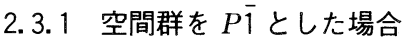

Woolfson らによって開発された MULTAN 78 プロ グラムを用い ${ }^{5)}$, タンジェント式を用いる多重解法で直 接に構造因子の位相を推定した。 2.2 節で求めた規格化 構造因子， $E$ にこれらの位相を付けてフーリエ合成を 行って非対称単位内で $E$-マップの組を作った。まず, 絶対有効因子の最も大きい $E$-マップを選びピークを調 ベたが，この結晶は外壳電子数の差の小さい原子種で構 成されているために強度の似たピークが多数存在し, そ れらの数も必要原子数の 2 倍以上であった。このため, 各ピークに原子を対応させて適当な構造モデルを直ちに 決めることは困難であった。 そこで, 非対称単位中に存 在する $\mathrm{Ca}$ 原子数は 3 個であるが， $E$-マップのピーク のうち最大の群に属する 5 個すべてに Ca 原子を対応さ せ，この原子による位相を用いてフーリエ合成を行って 電子密度を求めた. 電子密度ピークのうち大きいものは 
Table 1. Final atomic parameters for $R=0.092$. Temperature factors are of the form $\exp \left[-\left(\beta_{11} h^{2}+\beta_{22} k^{2}+\beta_{33} l^{2}+2 \beta_{12} h k+\beta_{13} h \bar{l}+2 \beta_{23} k l\right)\right]$, and the values for anisotropic thermal parameters are multiplied by $10^{4}$. Estimated standard deviations are given in parentheses.

\begin{tabular}{|c|c|c|c|}
\hline ATOM & $\mathrm{x}$ & $\mathrm{Y}$ & $\mathrm{Z}$ \\
\hline$A(1)$ & $0.1529(3)$ & 0.51351 & 0.41901 \\
\hline & $0.1339(3)$ & 0.8879 i & 0.35131 \\
\hline & 0.12411 & 0.87931 & 0 . \\
\hline & 6) & 6) & \\
\hline & 0.41941 & 7) & \\
\hline 10 & $0.1273 i$ & $0.2314 i$ & \\
\hline ) & $0.1330(4)$ & $0.2312(4)$ & $15 i$ \\
\hline 3) & $0(4)$ & $0.0751(4)$ & $72 i$ \\
\hline 4) & $0.4018(4)$ & 4) & 0 . \\
\hline I (5) & 0.39961 & 4) & 0 . \\
\hline I (6) & 0.41561 & $3(4)$ & 0. \\
\hline (1) & $\begin{array}{l}(10) \\
(10)\end{array}$ & $\begin{array}{l}(10) \\
7(12)\end{array}$ & \\
\hline (3) & (10) & & \\
\hline (4) & $3(12)$ & (12) & \\
\hline (5) & $1(10)$ & $(11)$ & \\
\hline (6) & $(10)$ & $5(11)$ & \\
\hline & (11) & $0(11)$ & 0. \\
\hline & $\begin{array}{l}(9) \\
(10)\end{array}$ & (10) & \\
\hline & & & \\
\hline & & & \\
\hline & & & \\
\hline & & & \\
\hline & & & \\
\hline & & 011 & \\
\hline & $29(11)$ & $0.6404(11)$ & \\
\hline
\end{tabular}

90 個あった。これらを“原子”之呼ぶ。これらの“原子” のうちで約 $1.6 \AA$ 付近に他“原子” が 4 個配位し，更に これら 4 個の配位 “原子”相互間距離がすべてほぼ 2.5 Å゙あるものをSi 原子とした. また，後者の配位“原子” を $\mathrm{O}$ 原子とした．次に，ピークの大きい“原子”のう ちで，2A 以内に他 “原子” の存在しないものを $\mathrm{Ca}$ 原 子とした。

これらの $\mathrm{Ca}$, Si 及び $\mathrm{O}$ 原子による位相を用いて再 度フーリ工合成を行い, 得られた電子密度ピークに対し 上記と同様の操作を繰り返し，6 個全部の $\mathrm{SiO}_{4} 4$ 面体 とそれら同士の連結の様子及び $\mathrm{Ca}$ 原子の位置を見いだ した. $\mathrm{SiO}_{4} 4$ 面体の大きさ, それら同士の連結状態及 び $\mathrm{Ca}-\mathrm{O}$ 間距離が適当であると判断できたので，この 構造の原子パラメーターをブロック近似最小二乗法によ り精密化し $\mathrm{Na}$ 原子の位置も確定した. 原子構造因子は $\mathrm{Na}, \mathrm{Ca}, \mathrm{Si}, \mathrm{O}$ 原子の值を使用した ${ }^{7)}$. 計算に用いた 回折斑点は 2222 個である. 原子パラメーターの変化が 誤差の範囲に入ったところで精密化を終了した. 信頼度 因子は， $R=0.092$ となった。このときの原子パラメ一 夕一を表 1 に，また，実測構造因子及び表 1 の原子パラ メーターに基づく計算構造因子を別表に示す*.

\subsection{2 空間群を $P 1$ とした場合}

大略の構造を知る目的で, 吸収補正を行っていない回 折強度に基づいて予備的な構造解析を行ったとき，この 空間群でも前項の構造と同類の構造となったので, 今回

* Final observed and calculated structure factors have been deposited with The Ceramic Society of Japan. Copies may be obtained through the Executive Secretary; The Ceramic Society of Japan, 2-22-17, Hyakunin-cho, Shinjuku-ku, Tokyo 160 Japan.

$\begin{array}{ccccccc}\beta_{11} & \beta_{22} & \beta_{33} & \beta_{12} & \beta_{13} & \beta_{23} \\ 31(3) & 40(3) & 44(6) & -25(2) & -14(3) & 20(3) \\ 26(3) & 33(3) & 40(6) & -17(2) & -7(3) & 18(3) \\ 26(3) & 41(3) & 45(6) & -20(2) & -11(3) & 21(3) \\ 35(6) & 44(7) & 65(12) & -20(5) & -4(7) & 24(7) \\ 44(7) & 43(7) & 205(19) & -15(6) & 23(9) & 31(9) \\ 18(3) & 30(4) & 35(7) & -17(3) & -11(4) & 16(4) \\ 26(4) & 30(4) & 29(7) & -19(3) & -10(4) & 12(4) \\ 23(4) & 30(4) & 28(7) & -18(3) & -10(4) & 11(4) \\ 33(4) & 29(4) & 30(7) & -23(3) & -10(4) & 15(4) \\ 29(4) & 30(4) & 34(7) & -18(3) & -8(4) & 13(4) \\ 20(3) & 26(4) & 33(7) & -18(3) & -12(4) & 13(4) \\ 32(10) & 35(10) & 27(19) & -23(8) & -2(11) & 12(11) \\ 31(10) & 60(13) & 20(20) & -19(9) & -2(12) & 11(12) \\ 35(10) & 51(12) & 20(19) & -31(9) & -10(11) & 17(12) \\ 58(12) & 48(12) & 66(23) & -8(10) & 9(13) & 43(14) \\ 29(10) & 50(11) & 65(22) & -30(9) & -10(12) & 38(13) \\ 31(10) & 43(11) & 76(23) & -15(9) & -22(12) & 42(13) \\ 36(11) & 38(11) & 65(22) & -18(9) & -10(12) & 14(13) \\ 15(9) & 42(11) & 50(21) & -23(8) & -7(11) & 19(12) \\ 27(10) & 24(10) & 38(20) & -19(8) & -9(11) & 3(11) \\ 69(13) & 67(14) & 92(26) & -10(11) & -2(15) & 66(16) \\ 39(11) & 70(14) & 76(23) & -37(10) & -21(13) & 44(15) \\ 51(11) & 35(11) & 22(19) & -21(9) & -1(12) & 12(12) \\ 44(11) & 46(12) & 102(25) & -31(9) & -21(13) & 53(14) \\ 35(10) & 48(12) & 55(21) & -26(9) & -5(12) & 23(13) \\ 32(10) & 52(12) & 74(23) & -16(9) & 12(13) & 31(14) \\ 36(11) & 51(12) & 75(23) & -33(9) & -8(12) & 31(13) \\ & & & & & & \end{array}$

は構造解析の初めの部分を省略し, 前項の $P \overline{1}$ の場合の 原子パラメーターに $\overline{1}$ で生ずる原子のパラメーターを加 えて $P 1$ 空間群で精密化を行った。しかし精密化は進ま ず，信頼度因子も0.092より向上しなかった。そこで， 本報告では対称性の高い $P \overline{1}$ 空間群の場合について結晶 構造を記述する。なお, 本章の計算には京都大学薬学 部で作製した KPAX 結晶構造解析用プログラム集 ${ }^{6 !}$ 利用し，京都大学共同利用 FACOM M-190 電算機で計 算処理を行った.

\section{3. 考 察}

\section{1 $\mathrm{Ca}_{3} \mathrm{Na}_{2} \mathrm{Si}_{6} \mathrm{O}_{16}$ の結晶構造}

表 1 の原子座標値に従って各原子を単位格子中に配置 し，これを $a$ 軸に沿って投影したものが図 1 で， $b$ 軸 に沿って投影したものが図 2 である. $\mathrm{SiO}_{4} 4$ 面体の連 結状態を示すため, 隣接する単位格子中の原子も一部追 加した。単位格子は細線で示す。困 1 及び図 2 中の番号 は表 1 ，表 2 及び表 4 と共通である。各図で, 大円は $\mathrm{O}$ 原子, 小円は Si 原子, 中円で点模様を有するものは $\mathrm{Ca}$ 原子, 中円白丸は $\mathrm{Na}$ 原子をそれぞれ示す。この結 晶は， $\beta$-ワラストナイト結晶 ${ }^{8)}$ の骨組をなしている 3 個 の $\mathrm{SiO}_{4} 4$ 面体を周期とする単鎖（ワラストナイト鎖と 呼ぶ）が 4 本縮合して 4 重の複鎖（デビトライト帯と呼 ぶ）となりこれれが $c$ 軸方向に並んだ構造を有している. $a$ 軸, $b$ 軸方向ではこれらデビトライト帯同士は Si-O-Si 結合によっては結ばれていない。 $c$ 軸方向に伸 びた 4 本のワラストナイト鎖のうち中央の 2 本は $\mathrm{SiO}_{4}$ 4 面体の 4 員環と 6 員環を形成する. 図 1 ではこれら両 環の構成を示すため中央の 2 本の鎖に含まれる原子並び 


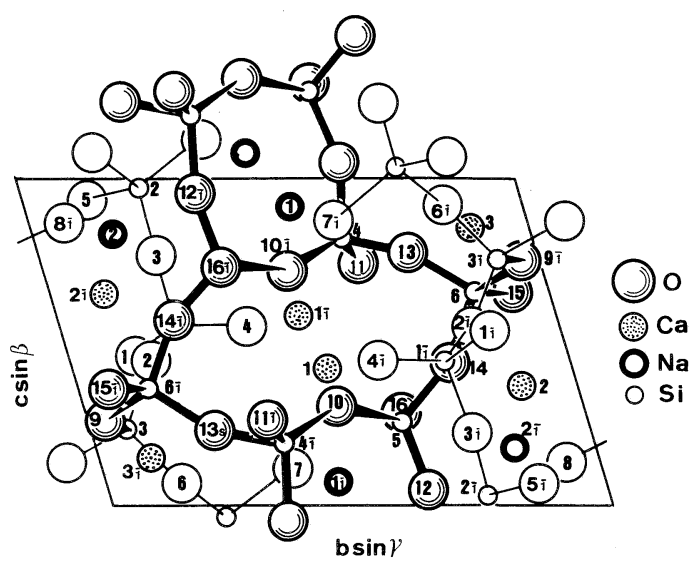

Fig. 1. Projection of the structure of $\mathrm{Ca}_{3} \mathrm{Na}_{2} \mathrm{Si}_{6} \mathrm{O}_{16}$ along the $a$-axis. Right hand axes. The small, boldly lined, dotted and large circles represent silicon, sodium, calcium and oxygen atoms, respectively. The unit cell is indicated by a parallelogram. Four wollastonite chains condense into a quadruple chain (the devitrite band). 4- and 6-membered rings of $\mathrm{SiO}_{4}$ tetrahedron formed by the inner two chains in the band are shown by bold lines. The numbering of atoms is consistent with those of Tables 2 and 4 . The devitrite bands run parallel to the $c$-axis and are bonded to each other only by $\mathrm{Ca}^{2+}$ and $\mathrm{Na}^{+}$ions. 1 indicates the atoms translated by the symmetry operation.

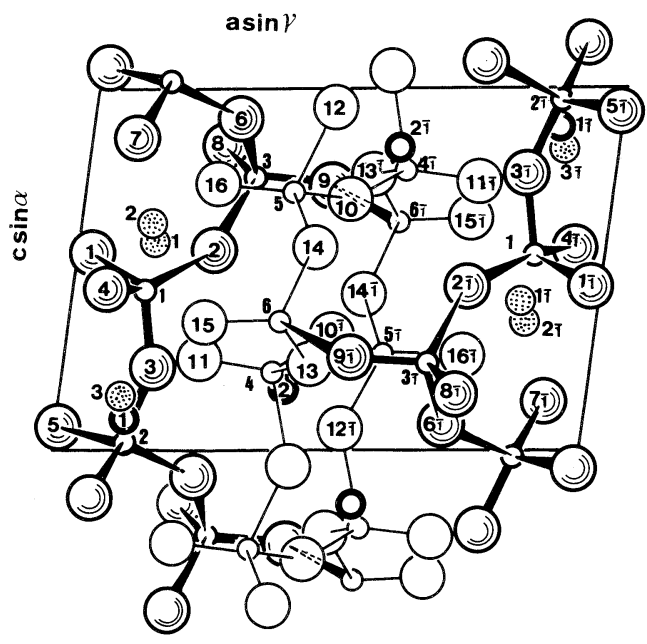

Fig. 2. Projection of $\mathrm{Ca}_{3} \mathrm{Na}_{2} \mathrm{Si}_{6} \mathrm{O}_{16}$ along the $b$-axis. Right hand axes. Atoms are shown by the same kinds of circles as in the Figure 1. The unit cell is indicated by a parallelogram. Both outside chains are shown by bold lines and are bonded to an inside double chain by the $\mathrm{Si}(3)-\mathrm{O}(9)-\mathrm{Si}(6) \overline{1}$ or by the $\mathrm{Si}(3) \overline{1}-\mathrm{O}$ (9) $\overline{1}-\mathrm{Si}(6)$ bridge at every third $\mathrm{SiO}_{4}$ tetrahedra, forming 8 -membered rings. $\overline{1}$ indicates the atoms translated by the symmetry operation.
に Si-O 間の結合を太線で示した. 図 2 では逆に両端の 鎖に関連するもののみを太線で示す。両端の 2 本の鎖は それぞれ中央の 2 重鎖と $\mathrm{SiO}_{4} 4$ 面体 3 個目ごとに連結 して, $\mathrm{SiO}_{4} 4$ 面体の 8 員環を作っている(図2).この 連結は, 結合 Si ( 3 )-O ( 9 )-Si ( 6 ) 1 及び結合 Si ( 3 ) 1-O（9)ㄱ-Si（6）のところで起こる（図 1 及び図 2 ). ここで, 1は対称操作で別の非対称単位に移った原子を 示す. 牧 ${ }^{31}$ はデビトライトの $c$ 軸の長さが $\beta$-ワラストナ イトの $b$ 軸の長さとほとんど等しいことから, デビト ライト結晶中にはワラストナイト鎖が 2 本縮合した 2 重 複鎖があると推定した。

本結晶は, 牧の推定どおり縮合したワラストナイト鎖 を含むが，ただ 2 重複鎖ではなく 4 重複鎖である.

Belov ${ }^{9)}$ は，例えば $\mathrm{Ca}^{2+} や \mathrm{Na}^{+}$などのよう半径の大き い陽イオンや中程度の半径の陽イオンを含むケイ酸塩で は単純鎖が縮合し，6員環のみの複鎖を生ずる小さい陽 イオンの場合とは異なり，4員環，6員環，8員環やま れには 5 員環を含む複鎖となり，更に縮合が進めばこれ ら各種の環で構成される 2 次元的無限網目構造を生ずる ことを発見した. Belov は図 3 a のワラストナイト鎖が 2 本縮合するとき, 繰り返し単位 2 個当たり $O$ が 1 個 余り式, $2\left[\mathrm{Si}_{3} \mathrm{O}_{9}\right]_{\infty}-\mathrm{O}=\left[\mathrm{Si}_{6} \mathrm{O}_{17}\right]_{\infty}$ に従って, 図 $3 \mathrm{~b} の$ ゾノトライト帯 (Xonotlite band) (ゾノトライト : $\mathrm{Ca}_{6}$ $\left.\left(\mathrm{Si}_{6} \mathrm{O}_{17}\right)(\mathrm{OH})_{2}\right)$ •を生ずることを示した ${ }^{9)}$. 本報のデビ トライト帯の構成はこのゾノトライト帯 2 本が過程, 2 $\left[\mathrm{Si}_{6} \mathrm{O}_{17}\right]_{\infty}-\mathrm{O}=\left[\mathrm{Si}_{12} \mathrm{O}_{33}\right]_{\infty}$ に従って形成したもの，すな わち, 図 $3 \mathrm{~b}$ から図 $3 \mathrm{c}$ が形成したものと考えられる. 次に， $c$ 軸に沿った投影を図 4 に示す。図 4 で，4 本の ワラストナイト鎖が $\mathrm{S}$ 字形に連結してデビトライト帯 を形成すること及び独立のデビトライト帯が $\mathrm{Ca}^{2+}$ 及び $\mathrm{Na}^{+}$イオンで相互に結合されることが分る.

各原子間距離を表 2 及び表 4 に示す. 各 $\mathrm{SiO}_{4} 4$ 面体
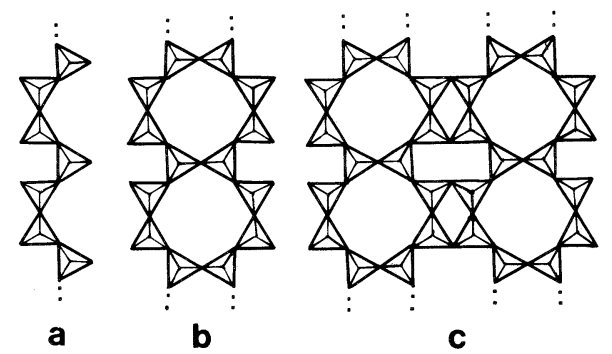

Fig. 3. Condensation of wollastonite (pyroxenoid) chains into devitrite bands with 4-,6-, and 8-membered rings by the Belov rule ${ }^{91}$ for silicate groups with large and middle size cations such as $\mathrm{Ca}^{2+}$ and $\mathrm{Na}^{+}$. The devitrite type band will be composed of xonotlite type bands according to the formula 2 $\left[\mathrm{Si}_{6} \mathrm{O}_{17}\right]_{\infty}-\mathrm{O}=\left[\mathrm{Si}_{12} \mathrm{O}_{33}\right]_{\infty}$. a : Wollastonite chain, $\left[\mathrm{Si}_{3} \mathrm{O}_{9}\right]_{\infty} ; \mathrm{b}$ : Xonotlite band, $\left[\mathrm{Si}_{6} \mathrm{O}_{17}\right]_{\infty} ; \mathrm{c}:$ Devitrite band, $\left[\mathrm{Si}_{12} \mathrm{O}_{33}\right]_{\infty}$. 


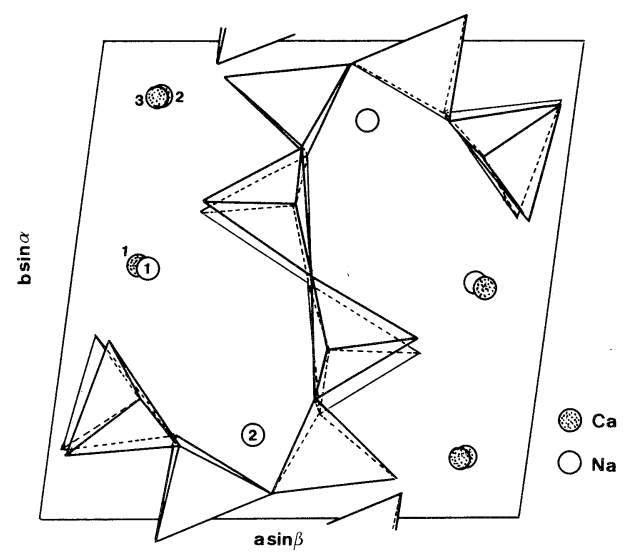

Fig. 4. The structure of $\mathrm{Ca}_{3} \mathrm{Na}_{2} \mathrm{Si}_{6} \mathrm{O}_{16}$, viewed in parallel to [001]. The unit cell is indicated by a parallelogram. Only the $\mathrm{Na}$ and $\mathrm{Ca}$ atoms are shown by open and dotted circles, respectively. The remainder of the structure is shown in tetrahedral representation. Wollastonite chains condense into a band which is bent in S-shape. The band is bonded to each other only by $\mathrm{Na}^{+}$and $\mathrm{Ca}^{2+}$ cations.

Table 2. Interatomic distances in devitrite.

\begin{tabular}{|c|c|c|c|}
\hline \multicolumn{4}{|c|}{$\begin{array}{l}\mathrm{SiO}_{4} \text { Tetrahedron } \\
(* \text { shows non-bridging oxygen.) }\end{array}$} \\
\hline $\begin{array}{l}\text { BOND } \\
\text { Si (1)-O(1) * } \\
\text { Si (1) }-O(2) \\
\text { Si (1) }-O(3) \\
\text { Si (1) }-O(4) \text { * }\end{array}$ & $\begin{array}{c}\dot{A} \\
1.610(11) \\
1.606(11) \\
1.615(11) \\
1.590(13)\end{array}$ & $\begin{array}{l}\text { BOND } \\
\text { Si }(2)-O(3) \\
\text { Si }(2)-O(5) \text { * } \\
\text { Si }(2)-O(6) \\
\text { Si }(2)-O(7) \text { * }\end{array}$ & $\begin{array}{l}A \\
1.626(13) \\
1.623(13) \\
1.635(2) \\
1.567(4)\end{array}$ \\
\hline $\begin{array}{l}\text { Si (3) }-O(2) \\
\text { Si }(3)-O(6) \\
\text { Si (3) }-O(8) \text { * } \\
\text { Si (3) }-O(9)\end{array}$ & $\begin{array}{l}1.615(10) \\
1.626(14) \\
1.583(11) \\
1.628(10)\end{array}$ & $\begin{array}{l}\text { Si (4)-O(10) } \overline{1} \\
\text { Si (4)-O(11)* } \\
\text { Si (4)-O(12) } \\
\text { Si (4)-O(13) }\end{array}$ & $\begin{array}{r}1.595(14) \\
* 1.566(11) \\
1.614(4) \\
1.618(14)\end{array}$ \\
\hline $\begin{array}{l}\text { Si (5) }-O(10) \\
\operatorname{Si}(5)-O(12) \\
\operatorname{Si}(5)-O(14) \\
\operatorname{Si}(5)-O(16)\end{array}$ & $\begin{array}{r}1.620(14) \\
1.608(13) \\
1.623(11) \\
\star 1.584(12)\end{array}$ & $\begin{array}{l}\text { Si }(6)-O(9) 1 \\
\text { Si } 6)-O(13) \\
\text { Si } 6)-O(14) \\
\text { Si } 6 \text { (6)-O(15)* }\end{array}$ & $\begin{array}{r}1.628(4) \\
1.617(14) \\
1.614(10) \\
1.564(10)\end{array}$ \\
\hline
\end{tabular}

$\mathrm{CaO}_{\mathrm{n}}$ Polyhedron

\begin{tabular}{|c|c|c|c|}
\hline $\begin{array}{l}\text { BOND } \\
\mathrm{Ca}(1)-O(4) \\
\mathrm{Ca}(1)-O(4) \overline{1} \\
\mathrm{Ca}(1)-O(7) \\
\mathrm{Ca}(1)-O(11) \\
\mathrm{Ca}(1)-O(16)\end{array}$ & $\begin{array}{l}\dot{A} \\
2.311(15) \\
2.262(3) \\
2.265(10) \\
2.401(10) \\
2.408(14)\end{array}$ & $\begin{array}{l}\text { BOND } \\
\mathrm{Ca}(2)-O(1) \\
\mathrm{Ca}(2)-O(1) \bar{I} \\
\mathrm{Ca}(2)-\mathrm{O}(5) \overline{1} \\
\mathrm{Ca}(2)-\mathrm{O}(8) \\
\mathrm{Ca}(2)-\mathrm{O}(15) \\
\mathrm{Ca}(2)-\mathrm{O}(16)\end{array}$ & $\begin{array}{l}\dot{A} \\
2.479(3) \\
2.315(3) \\
2.363(3) \\
2.270(12) \\
2.328(11) \\
2.538(11)\end{array}$ \\
\hline $\begin{array}{l}\mathrm{Ca}(3)-O(1) \overline{1} \\
\mathrm{Ca}(3)-O(5) \\
\mathrm{Ca}(3)-O(5) \mathrm{I} \\
\mathrm{Ca}(3)-O(8) \bar{I} \\
\mathrm{Ca}(3)-O(11) \\
\mathrm{Ca}(3)-O(15)\end{array}$ & $\begin{array}{l}2.382(3) \\
2.554(3) \\
2.361(4) \\
2.297(3) \\
2.590(12) \\
2.272(13)\end{array}$ & & \\
\hline On $_{\text {n }}$ lyhed & dron & & \\
\hline $\begin{array}{l}\text { BOND } \\
\mathrm{Na}(1)-O(3) \\
\mathrm{Va}(1)-O(4) \\
\mathrm{Na}(1)-O(7) \\
\mathrm{Va}(1)-O(7) \overline{1} \\
\mathrm{Va}(1)-O(11) \\
\mathrm{Ta}(1)-O(16)\end{array}$ & $\begin{array}{c}\dot{A} \\
2.793(12) \\
2.573(11) \\
2.475(8) \\
2.277(6) \\
2.463(16) \\
2.543(6)\end{array}$ & $\begin{array}{l}\text { BOND } \\
\mathrm{Na}(2)-\mathrm{O}(2) \\
\mathrm{Na}(2)-\mathrm{O}(3) \\
\mathrm{Na}(2)-\mathrm{O}(6) \\
\mathrm{Na}(2)-\mathrm{O}(9) \overline{1} \\
\mathrm{Na}(2)-\mathrm{O}(12) \overline{\overline{1}} \\
\mathrm{Na}(2)-\mathrm{O}(13) \overline{\overline{1}} \\
\mathrm{Na}(2)-\mathrm{O}(14) \overline{\overline{1}}\end{array}$ & $\begin{array}{c}\dot{A} \\
2.922(13) \\
2.359(12) \\
2.510(9) \\
2.228(7) \\
2.433(8) \\
2.852(8) \\
2.585(9)\end{array}$ \\
\hline
\end{tabular}

Table 3. Si-O distances in some simple silicates (after Baltă) ${ }^{11}$.

\begin{tabular}{l|lc}
\hline \multirow{2}{*}{ Component } & \multicolumn{2}{|c}{ Distance $\AA$} \\
& Si-O(b) & Si-O(nb) \\
\hline$\alpha$-quartz & 1.62 & -- \\
$\alpha$-cristobalite & 1.62 & -- \\
$\alpha$-Na20.2SiO2 & 1.63 & 1.578 \\
$\beta$-Na20.2SiO2 & 1.639 & 1.580 \\
Na2O.SiO2 & 1.672 & 1.592 \\
CaO.SiO2 & 1.655 & 1.598 \\
\hline \multicolumn{2}{c}{ b:bridging oxygens. } \\
nb:non-bridging oxygens.
\end{tabular}

Table 4. Interatomic distances between cations $(<5 \AA)$.

\begin{tabular}{lllc}
$\quad$ Bond & $\AA$ & \multicolumn{1}{c}{ Bond } & $\AA$ \\
$\mathrm{Na}(1)-\mathrm{Na}(1) \overline{1}$ & $3.272(7)$ & $\mathrm{Na}(1)-\mathrm{Ca}(1) \overline{1}$ & $3.484(6)$ \\
$\mathrm{Na}(1)-\mathrm{Na}(2)$ & $4.107(9)$ & $\mathrm{Na}(1)-\mathrm{Ca}(1)$ & $3.552(8)$ \\
& & $\mathrm{Na}(1)-\mathrm{Ca}(1)$ & $3.575(7)$ \\
$\mathrm{Ca}(1)-\mathrm{Ca}(1) \overline{1}$ & $3.543(4)$ & $\mathrm{Na}(1)-\mathrm{Ca}(3)$ & $4.009(8)$ \\
$\mathrm{Ca}(2)-\mathrm{Ca}(3)$ & $3.560(5)$ & $\mathrm{Na}(1)-\mathrm{Ca}(2)$ & $4.090(6)$ \\
$\mathrm{Ca}(3)-\mathrm{Ca}(3) \overline{1}$ & $3.589(3)$ & & \\
$\mathrm{Ca}(2)-\mathrm{Ca}(2) \overline{1}$ & $3.615(3)$ & $\mathrm{Na}(2)-\mathrm{Ca}(2) \overline{1}$ & $4.703(4)$ \\
$\mathrm{Ca}(2)-\mathrm{Ca}(3) \overline{1}$ & $3.678(3)$ & $\mathrm{Na}(2)-\mathrm{Ca}(2)$ & $4.770(3)$ \\
$\mathrm{Ca}(1)-\mathrm{Ca}(3)$ & $4.034(4)$ & $\mathrm{Na}(2)-\mathrm{Ca}(3)$ & $4.804(4)$ \\
$\mathrm{Ca}(1)-\mathrm{Ca}(2)$ & $4.140(5)$ & $\mathrm{Na}(2)-\mathrm{Ca}(3) \overline{1}$ & $4.890(3)$ \\
& & & \\
$\overline{1}$ indicates the atoms & translated by the \\
symmetry operation.
\end{tabular}

の $\mathrm{Si}-\mathrm{O}$ 間距離はどれも他のケイ酸塩結晶中での值 ${ }^{10\}}$,

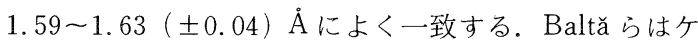
イ酸及び簡単な組成のアルカリ及びアルカリ土類ケイ酸 塩においては， $\mathrm{SiO}_{4} 4$ 面体の $\mathrm{Si}-\mathrm{O}$ 間距離が非架橋酸 素の場合に架橋酸素の場合よりかなり短く，更に 4 面体 1 個当たりの非架橋酸素数が 1 個から 2 個に増すと $\mathrm{Si}-\mathrm{O}$ 間距離が全体的に伸びることを紹介した (表 3$)^{11 !}$ 。 本結晶の場合にも, 表 2 中で*印を付して示した非架橋 酸素からの Si-O 間距離が架橋酸素からのそれよりかな り短いので, 表 3 の簡単なケイ酸塩の場合と同様に, こ の結晶の $\mathrm{SiO}_{4} 4$ 面体はいずれも正 4 面体ではない。一 般に， $\mathrm{Ca} ， \mathrm{Na}$ 原子とこれらに配位する $\mathrm{O}$ 原子との距 離は酸素配位数で多少変化するが， Ca 原子の場合に $2.29 \sim 3.01 \AA ， \mathrm{Na}$ 原子の場合には $2.22 \sim 2.75 \AA$ の範囲 にある ${ }^{101}$. そこで，各 $\mathrm{Ca}$ 及び $\mathrm{Na}$ 原子から $3.0 \AA$ 以内 にある $\mathrm{O}$ 原子を配位酸素之考え，これらへの $\mathrm{Ca}-\mathrm{O}$ ， $\mathrm{Na}-\mathrm{O}$ 間距離を表 2 に示す.

これらの距離は上記の值とよく合致している．表 2 か らこの結晶の構造式は $\mathrm{Ca}^{[5]} \mathrm{Ca}_{2}{ }^{[6]} \mathrm{Na}^{[6]} \mathrm{Na}^{[7]} \mathrm{Si}_{6}{ }^{[4]} \mathrm{O}_{16}$ となる (大括弧内は酸素配位数を示す)。本結晶の $\mathrm{Ca}^{2+}$ と $\mathrm{Na}^{+}$ の陽イオン間距離で $5 \AA$ 以下のものを表 4 に示す．各陽 イオン間の距離がほぼ $3.5 \AA$ 付近と $4.0 \AA$ 付近に集中し ている.

\section{4. 総 括}

$\mathrm{Na}_{2} \mathrm{MoO}_{4}$ を融剤としてデビトライトの単結晶を合成 し，X線回折法によって構造を解析した。この結晶中 
ではワラストナイト鎖が 4 本縮合して 1 次元の 4 重鎖を 形成している。これをデビトライト帯と名付けた。デビ トライト帯は $c$ 軸方向に並び, $\mathrm{Ca}^{2+}$ 及び $\mathrm{Na}^{+}$イオンで 相互に結合されている. 本結晶は半径の大きい陽イオン や中程度の半径の陽イオンを含むケイ酸塩で，単純鎖か ら始まりこれが縮合してゆき最後に2 次元網目構造を形 成するケイ酸塩群の一員であり，これらの群のものによ くみられる 4 員環, 6 員環及び 8 員環を有している.

謝辞 研究費の一部として日本板硝子(株)材料工学助 成金を使用致しましたことを記し，深謝致します。

\section{文献}

1) G. W. Morey and N. L. Bowen, J. Soc. Glass Techn., 226-30 (1925).

2）牧巌, 杉村 隆, 窯協, 76, 204-06 (1968).

3) I. Maki, Yogyo-Kyokai-Shi, 76, 203 (1968).

4) 小谷和司, 京都工芸繊維大学卒業論文 (1981).
5) P. Main, S. E. Hull, L. Lessinger, G. Germain, J. P. Declercq and M. M. Woolfson, MULTAN 78, "A System of Computer Programs for the Automatic Solution of Crystal Structures from X-ray Diffraction Data", Univ. of York, Engl and and Louvain, Belgium.

6) KPAX Program System, Faculty of Pharmaceutical Sciences, Kyoto Univ.

7) International Tables for X-ray Crystallography, Vol. IV, Kynoch Press, Birmingham (1974) p. 71

8) R.W.G. Wyckoff, "Crystal Structure", Vol.4, John Wiley (1968) p. 314.

9) V.N. Belov, "Crystal Chemistry of Large-cation Silicates”, (Acad. Sci. URSS, Moscow, 1961), English translation: Consultants Bur., NY. (1962) Cited in J. Zarzycki, "Physics of Non-crystalline Solids", J.A. Prins Editor, North-Holland Publishing Co., Amsterdam (1965) p. 525-48.

10) International Tables for X-ray Crystallography Vol. III, Kynoch Press, Birmingham (1962) p. 258-64.

11) P. Baltă and E. Baltă, "Introduction to the Physical Chemistry of the Vitreous State", Abacus Press, England (1976) p. 152. 